\title{
Realization of a Desired Future: Innovation in Education
}

\author{
Fuat Fındıkoğlu*, Dilek İlhan \\ Faculty of Education, Yildiz Technical University, Turkey
}

Copyright $(2016$ by authors, all rights reserved. Authors agree that this article remains permanently open access under the terms of the Creative Commons Attribution License 4.0 International License

\begin{abstract}
Today and tomorrow, the world needs individuals who can manipulate critical and creative thinking skills to solve problems as a team. With technology, the way knowledge is obtained, constructed and communicated have completely transformed and altered. When it comes to education, it is a matter of question whether education is capable of creating critical and creative thinkers who can answer the needs of social and economic world of today and tomorrow. On the other hand, computers and smart devices are threatening the integrity of knowledge and knowing by damaging the authority of teachers in classrooms changing the way teachers are perceived. Therefore, terms such as guide, facilitator or coach have started to sound interchangeable with the word teacher. It is a widely known fact that schools are the learning environments for children. However, it is not certain how much they learn and how much of the content is supported by the ICTs. At an age when people are surrounded by technology all the time at work, in schools and everywhere, technological tools and smart devices have advanced too fast. The advances in technological devices used every day have gone faster than the advances in educational research and pedagogical approaches which incorporate educational technologies. This being the case, innovation in educational activities can be ensured through an understanding of the benefits of using technologies in education. This study is aimed at presenting that innovation in education is to be handled carefully. In order for this, this paper reviews the previous studies regarding innovation as a prerequisite for novel learning environments and revising strategies for successful adaption of technology to education, thus creating innovative learning environments. In conclusion, innovation is of vital importance in transforming and reconstructing the learning environments along with the curricula, the role of the teacher and teacher training.
\end{abstract}

Keywords Innovation, Education, Educational Technology, Change in Education, Curriculum

\section{Introduction}

In today's world, people have now acquired full citizenship to the knowledge society. Voogt [29] suggests that the reason why the global society has transformed into knowledge society is the ICTs. What is odd about living in the contemporary world is that the individual cannot deny the changes in the world; he must readily adapt to the changing environment and conditions, which is a quality of technology-driven societies. This fact puts a pressure on educational systems to adapt all individuals to knowledge society and knowledge economy. As for a combination of knowledge society and global economy, the infrastructure of today's society is based on building knowledge. Educational systems, namely curricula, must be redesigned in a way that they will raise critical and creative thinkers that will focus on contributing to knowledge society. Knowledge building, problem-solving and innovation, skilled communication, collaboration, self-regulation and the use of technology for learning are the very learning outcomes of the $21^{\text {st }}$ century [19], among which self-regulation that puts the student at the center of educational processes will be the key; as emphasized by Ilhan and Karatas [11] in that the students take active part in the learning process, which will pave the way for the students to become knowledge builders. Innovation in education, as the name suggests and unlike the traditional educational settings, will transform the students from 'knowledge consumers' into 'knowledge manufacturers' by placing them at the center of innovative educational settings. Therefore, what will take the global society today to the future is knowledge and innovation [21]. That puts a heavy load on educational systems to raise individuals with high innovative skills and knowledge production capacity. As knowledge is not the result of scientific studies any longer; rather, it is a way of raising skilled problem solvers and individuals who will maintain their learning all their lives [17].

Given the present situation of the world and global and knowledge economy today, the shortest possible ways of integrating educational systems into the knowledge economy are reconstructing the concept of knowledge, understanding what innovation really means and enriching human capital through the increased rates of schooling [22]. Blouin et al. [2] draw attention to the fact that students are ready for this reconstruction but the faculty members and the institutions 
may not be as ready and suggest that this transformation requires extreme caution. For technology adoption into the learning environments and keeping up with technological advances, Findikoglu, Alci and Karatas [9] puts forward that individuals should take active part in adopting technology as it is not very probable to include every newly-released instructional technology or ICTs in curricula, which are hardly designed on annual basis and to which it's not very traditional to make any upgrades during the year. Here, Bocconi, Kampylis and Punie [3] associate innovation and modernization of educational activities with creative and critical learners, who can take control of their own learning and monitor their own progress themselves. Salampasis [23] makes a clear distinction between innovation and creativity by putting forward that innovation happens as a result of creative processes. Creativity, technically, is a form of knowledge manufacturing; or in other words, it is the knowledge manufactured.

On the other hand, innovation doesn't necessarily mean cutting-edge technology adoption. Because innovation and technology adoption may sometimes be confusing as the two terms sometimes happen to be used interchangeably. Also, innovation is mostly viewed as 'use of technology itself'. Pisanu and Menapes [20] clears the confusion by putting forward that innovation in education is needed to incorporate old and new technologies and educational environments that already exist may be adapted and upgraded through the use of technology.

\subsection{Purpose of the Study}

In the light of the theoretical framework provided above, this study seeks answers for the following questions:

1. What is the importance of innovation in educational settings?

2. How can innovation be ensured in education?

3. What is the true nature of the relationship between technology and curriculum?

\section{The Significance of Innovation in Education}

With the advent of latest technologies, it has become a trend to deploy what comes in handy at first glance among many gadgets and tools. As Seemann [31] phrased, innovation in education in terms of technology does not only mean creativity in designing materials or technologically-enhanced material design nor it's just a topic of discussion in theory or philosophy of teaching; rather, it does exist in practice and it does affect the output of the education with present expected innovative qualities and skills in individuals by the employers. Though the adjective "elusive" is an appropriate way of definition for these qualities and skills, Avvisati, Jacotin and Vincent-Lancrin [32] give three categories for these skills and qualifications technical skills, skills in thinking and creativity and behavioral and social skills - which altogether provide the individual with the power to innovate by putting a special emphasis that these can be learnt or enhanced through learning. This holds education accountable for equipping the students with the required skills that they will need for the current economy. The new economy today needs innovative and entrepreneurial individuals; but, the traditional educational system fails to raise those kind of individuals but raises employment-oriented individuals [33]. It can be said that innovation is a concept that relates mostly to the future economies and societies. For some part, it is already happening today in that many multi-national and corporate companies are requiring the above skills and qualifications already and they are driving the innovation economy, thus urging the system of education and its outputs to become more innovative and drive today's and tomorrow's economies and societies. As put forward by Turcsányi-Szabó [34], innovation must be fostered in the individuals prospective workforce - in the system of education for them to adjust to the changing work environments of the future. Also, Wagner [35] defines seven skills for careers, college and citizenship, which are critical thinking and problem-solving, collaboration among networks and leading by influence, agility and adaptability, initiative and entrepreneurialism, effective oral and written communication, accessing and analyzing information, curiosity and imagination. These can be said to constitute the fundamentals of being ready to innovate. Moreover, the individuals who happen to possess these skills would be the ultimate employees of the innovation economy. These skills are the constituents of the traits of the individuals who can manipulate their surroundings among the societies and economies. Unlike the traditional societies and economies, the innovation economy would require individuals who can go further beyond a degree from tertiary education. For example, beyond having technological skills, one will have to manipulate these skills into profits of any kind by all means possible. All these theories and expectations of the future do exist but one thing hasn't changed yet - education will still be responsible for whatever will be going on in the future no matter what technological advances will be achieved by then.

Sahlberg [36] brings a different perspective on the education-economy relationship by explaining the nature with the idea that human capital drives the economies and education cannot only be confined to be a matter of knowing or not knowing; it is rather manipulating knowledge so that it can be useful, which in the end refers to innovation and entrepreneurial processes that will lead to economic growth and social transformation.

The literature above clearly suggests that innovation has a significant role in the systems of education today, though the definitions as to how to start and manage it have not been thoroughly made. The role of the use of technology in education and how it relates to the content that needs to be conveyed to the students and the role of the knowledge that is part of that content need to be handled carefully while 
designing the curricula and the instructional environments and handling the outcomes of the instructional processes in terms of how to evaluate the value of workforce that will enter the market and consecutively their use for the economy and the services they will offer. This takes the nature of this relationship back to the objectives of the education that will shape the nature of the instructional processes.

No matter how difficult it may be to acknowledge the fact that technology isn't sufficient alone in education or any student who attended to a technologically-enhanced classroom would be an expert on the topic or learn anything, the curricular circumstances of what has already been perceived about technology will be in question sooner or later. Here, it becomes more and more important to take an innovative stance on education. This being the case, innovation isn't merely adopting the latest technology; it must be accepted as a process where the content to be communicated to the students is being coded in a more attractive and meaningful way through the use of technology. Therefore, instruction shouldn't solely be confined to conveying standard content to students no matter what advanced technological tools are being deployed in the process. Innovation should be taken into account in the ways that goals, content knowledge and learning outcomes are treated with an efficient perspective and approach.

In a report by OECD [18], it is clear that schools need strategies for adoption of innovative practices resulting from the fact that schools are incapable of managing research knowledge, networking, modular restructuring and technological development which are essential for innovation in education. However, it is not very easy to deploy innovative technologies in schools for the reasons that it necessitates changes in pedagogical, technological and managerial systems, which usually fails to meet the expectations in the beginning [28].

Shapiro, Haahr, Bayer and Boekholt [25] put forward that education for innovation involves learning and teaching approaches which incorporates activity based learning and hands-on experience, which is also a curricular and instructional design-related theory rather than mere adoption of technological tools. Merisotis and Phipps [16] add to the idea by stating that most of the research on technology eventually focuses on an activity that directly relates to the art of teaching by concluding that technology adoption is not as significant as other elements such as motivation, teacher, learner characteristics, learning tasks, etc. As a result, it can be said that innovation is more related to curricula than it is thought to technology.

\section{Innovation in Education}

Under the light of literature provided until now, innovation in education can roughly be defined as the ways of coming up with alternative ways of ensuring behavioral change in individuals if/when the current way (learning theory/learning task/teaching method/learning approach, etc.) is not working effectively. The two old terms of teaching and learning seem to be replaced by the novel terms of innovation and self-regulation. It is logical to think that, in a world where the individuals are transforming the world and being transformed by the global world, old teaching methodologies, beliefs and ways are more like to have no practical use soon. Shavinina [26] defines innovation in education as interference in educational activities of students for raising them as innovative adults. With too much emphasis on the relationship between innovation and curricular and instructional activities, on the other hand, the relationship between innovation and ICTs cannot be underestimated.

Kampylis, Bocconi and Punie [12] classifies the interrelated nature of innovation, technology and curriculum by stating that the role of ICTs must be disruptive which is to result in the transformation of teachers' and students' roles and innovation in pedagogical aspect which can eventually be ensured through a transformation in values, practices and infrastructure. This may partly be the case; however, focusing on the ultimate goal of teaching and schooling, innovation, which is when the student has a behavioral change, he has got what he came for in the first place. Moreover, innovative strategies serve as an alternative to the traditional strategies which may be outdated or do not attract the students' attention any longer. Schneckenberg [24] suggests a complementary function of ICTs in a way to implement innovative educational concepts to the classrooms. Simplicio [27] emphasizes that dramatic changes are required in the three elements of teaching, which are the content, method of teaching and assessment. The key to these changes is the trio of teacher, curriculum and the educational settings. Burnard [4] mentions about the necessity of curriculum and assessment-related research that will bring about innovative practices to teaching.

Cerna [7] stresses that innovative activities are taking place in schools and classrooms where talented and creative school leaders are driving innovation in education. Shapiro, Haahr, Bayer and Boekholt [25] suggests that an unconventional learning setting can be provided with a representation of a problem from real-life setting with the introduction of problem-based learning.

Bakkenes, Vermunt and Wubbels [1] attach great importance to teachers as they are the ones who pave the way for innovation in educational settings. By suggesting an amelioration of teacher training programs, Ferrari, Cachia and Punie [8] acknowledges that technology has a capability of invoking creative learning and innovative teaching; but still, this capability will be minimal if the teachers do not take active part in the innovation of education. Kirkland and Sutch [14] adds to this idea by putting forward that teachers' beliefs and attitudes will also have a great influence on innovation in education. Attention is drawn to the internal processes of teachers in the process of educational innovation by Henze and Driel [10].

The last of the three elements is the curricula. Cachia, Ferrari, Ala-Mutka and Punie [6] found out that, in a study 
they carried out, the term creativity was in most of the curricula across many European countries. In contrast, the term innovation was not that frequent. Curriculum is the broadest concept in educational innovation. Again, in curricular aspect of educational innovation, teachers' understanding and background determines the extent to which conveying of the innovative curricular content is going to be achieved [13].

Figure 1 suggests that the highest activity regarding innovation occurs among the teacher, curriculum and classroom trio. Teachers' interaction with the curriculum is significant in that he can control and monitor other variables within the educational system. Rogers [37] puts forward that unless the diffusion of innovations can be ensured, any attempts to innovate will most probably fail by giving several examples of innovative activities failing to diffuse because they weren't adopted by the general public stating the idea that innovation is difficult to be adopted by public in spite of its certain probable advantages. According to Ala-Mutka, Punie and Redecker [38], the introduction of technology for innovation in education into the learning environments all over Europe and the world haven't exhibited signs of desired transformation. The reason why is, from the perspective of Christensen, Johnson and Horn [39], that carrying on the traditional way of teaching the same content using only computer-aided materials. In general, using ICTs can only help teachers to code a core message (a goal and content) in an unconventional form that is targeted for students with different learning styles. In other words, given the current traditional educational systems, there is a specific content to be conveyed and teachers usually aim at following the steps in the curricula leaving the so-called innovative activities to be confined to the technological means over the traditional ones. Using only ICTs should neither merely mean innovation nor the ultimate goal in education. They merely facilitate the learning processes or make the organization of the content to be conveyed to students easier to understand, which in the end saves time and allocates more time for other type of activities or revisions/reinforcements. Innovation, on the other hand, means changing the way the students learn or teachers teach. Falch and Mang [43] describe innovative practices in education as teachers' responsibility for technology must be used to increase alternatives in methodology, thus putting the qualities of teachers in question. Innovation basically means providing alternatives or novel ways to already existing methods or approaches. When a need for a change or an urge for alternatives calls for attention, it can be said that innovative educational practices are taking place. That is to say, innovation in education can mean ameliorating the problems existing in practice at the moment. Taking education to an innovative level of practice requires teachers stopping the old routines and changing their old or traditional beliefs for the untraditional students and learning environments and social life at hand today [40]. An encouraging way of innovation in education would be the teachers searching for creative and innovative solutions to existing problems and carrying out research into instruction and education [41].

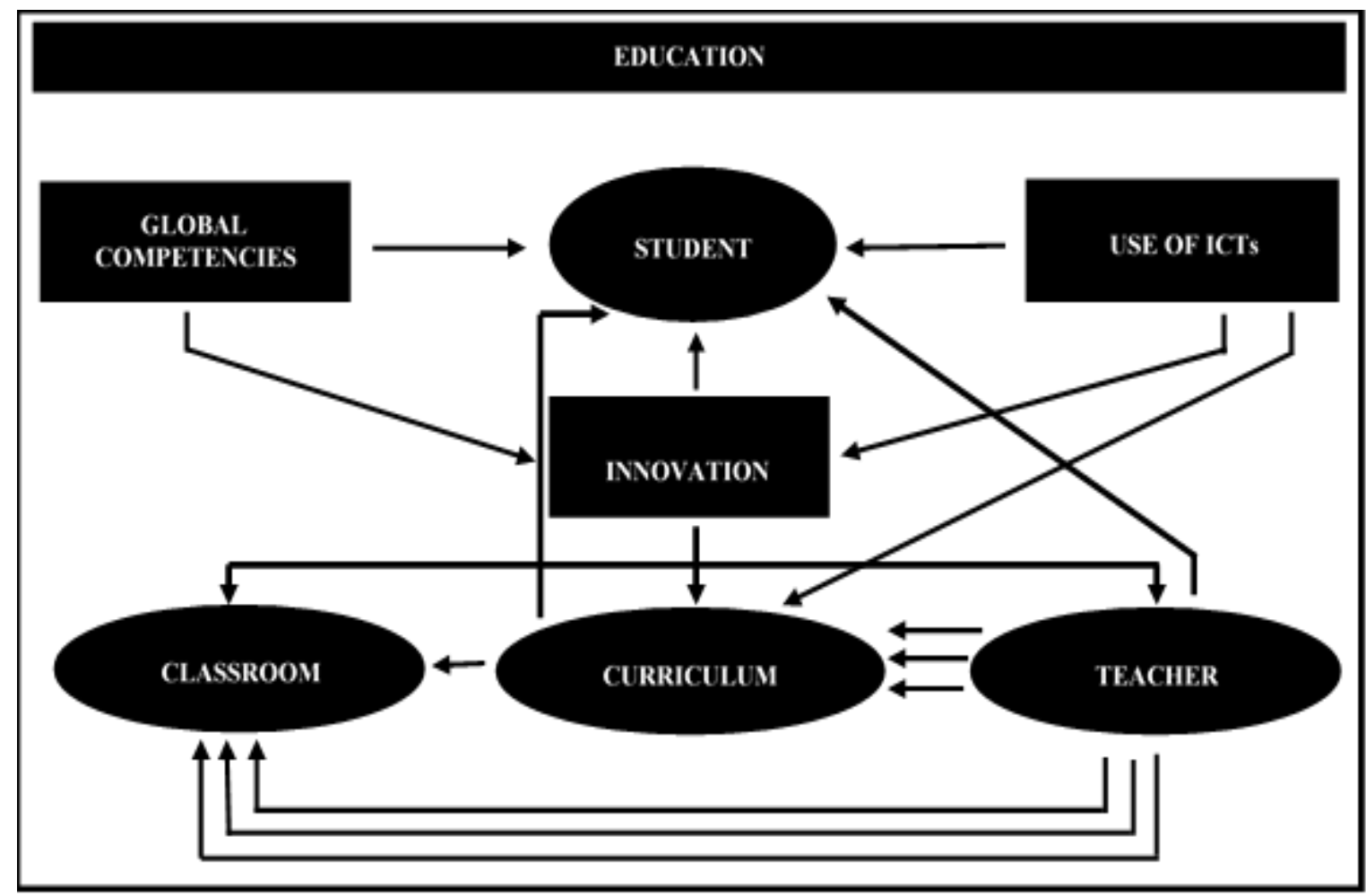

Figure 1. Classroom-curriculum-teacher trio relationship with regards to the variables in the system of education 


\section{Discussion and Conclusions}

Innovation has been used interchangeably with technology adoption in education. It is a popular hot topic in science today and also a hot topic of research in educational sciences. This being the case, as the type of society is knowledge society and knowledge economy today, everything is based on producing knowledge and managing it globally. This puts a pressure on education that individuals must be equipped with skills to compete in the knowledge era. The outcomes of the education system must be targeted to ensure that the outcomes are newly produced knowledge. Büyükuslu [5] predicts that, with the inescapable rise of innovation and science in the new world order, the world society will transform into an entrepreneurial society where innovative ideas of individuals will compete and meet the demands of the innovation economy. Sahlberg [42] also claims that knowledge and innovation are the elements that will make today's society transform into the future's. In this respect, for education must prepare the individuals to the innovation economy, education itself must transform and innovative practices must be nurtured.

Langworthy, Shear and Means [15] suggest that governments, systems and schools must develop techniques to measure to what degree innovative education is happening and what its implications of it on student learning and academic progress are and they also suggest that the goals of the educational systems must be synchronized with the demands of the $21^{\text {st }}$ century economies and societies.

The educational systems change the people and their societies and vice versa, the societies always transform and with themselves, they transform the inner dynamics of the country they belong to. Generally speaking, using ICTs is only a way of supporting the content of the curriculum. Teaching professionals must discriminate between innovation and using technology in education, both of which have attributions to different concepts.

In conclusion, it can be said that using technology in education can be a part of using innovative practices and innovation in education. Innovation itself fits better to the practices where curriculum-related levels of instruction are enhanced through technology or technologically enhanced materials, techniques and equipment. In other words, technology facilitates the conveying of the content to the students.

\section{Recommendations}

Despite the long history of innovation in economy, society and science, innovation in education can still be considered as something novel and needs further study. Literature and research also suggest that there is a very close relationship between innovation in education and technology adoption to education and even there are times that the terms are interchangeable with one another. However, there still should be made a detailed and thorough description of both terms and how to include them in curriculum design, instructional settings and instruction must be depicted with examples. How innovation and technology adoption is different needs to be clarified and why the need for innovation in education and technology adoption to education arises must be explored in educational settings.

\section{For Further Studies}

With the changing needs of the society and global world, the nature of education should be aligned with the requirements of the knowledge society and globalization. Case studies where the instruction fails to reach its goals or where there occurs a breakdown when conveying the content will be very useful to discriminate between innovation and ICT use. ICTs are already in use and usually are preferred for they provide ease of access to materials. However, there are still students who cannot fully understand the content and need further assistance. This will help teachers understand what innovation is really about and how it is any different than mere technology adoption. The results of these case studies will show teachers that a slight adaption to the teaching style or approach that is currently in use may be of better use for the students or that altering the style, technique, method or approach will be ideal. Furthermore, they can even realize that content may be reorganized in order to answer to individual differences and all. From Watson [30]'s study where education is said to be too much involved in learning about computers and the focus must be directed on simple, context-related tasks and pedagogy and knowledge a decade ago to today's world where technology adoption to education is still investigated with less focus on innovation and its relation to curriculum and teaching. Besides these, studies into innovation in education could also be associated with some ever-lasting studies, at which qualities such as motivation, perceptions, attitudes, achievement tests and burnout are investigated, for the purpose of taking advantage of better practical results.

\section{REFERENCES}

[1] I. Bakkenes, J. D. Vermunt, T. Wubbels. Teacher learning in the context of educational innovation: Learning activities and learning outcomes of experienced teachers Learning and Instruction, Vol.20, No.6, 533-548, 2010.

[2] R. A. Blouin, W. H. Riffee, E.T. Robinson, D. E. Beck, C. Green, P. U. Joyner, . . . G. M. Pollack. Roles of innovation in education delivery, American Journal of Pharmaceutical Education, Vol.73, No.8, 1-12, 2009.

[3] S. Bocconi, P. G. Kampylis, Y. Punie. Innovating learning: Key elements for developing creative classrooms in Europe, Spain, European Commission, Joint Research Centre, Institute for Prospective Technological Studies, 2012. 
[4] P. Burnard. Constructing assesment for creative learning, In J. Sefton-Green, P. Thomson, K. Jones, L. Bresler (eds.), The Routledge International Handbook of Creative Learning, 140-150, Abingdon, Routledge, 2011.

[5] A. R. Büyükuslu. İnovasyon ve girişimcilik ekonomisi ve yönetimi üzerine yazılar, İstanbul, Der Yayınevi, 2015.

[6] R. Cachia, A. Ferrari, K. Ala-Mutka, Y. Punie. Creative learning and innovative teaching, JRC Scientific and Technical Reports, Spain, European Commission, Joint Research Centre, Institute for Prospective Technological Studies, 2010.

[7] L. Cerna. Innovation, governance and reform in education, Paris, OECD, 2014.

[8] A. Ferrari, R. Cachia, Y. Punie. Innovation and creativity in education and training in the EU member states: Fostering Creative Learning and Supportive Innovative Teaching, Spain, European Commission, Joint Research Centre, Institute for Prospective Technological Studies, 2009.

[9] F. Findikoglu, B. Alci, H. Karatas. The correlation between pre-service teachers' attitudes towards technology and achievement in material design, Anthropologist, Vol.20, No.3, 744-753, 2015.

[10] I. Henze, J. H. Driel. Experienced science teachers' learning in the context of educational innovation, Journal of Teacher Education, Vol.60, No.2, 184-199, 2009.

[11] D. Ilhan, H. Karatas. An analysis on motivational beliefs and attitudes of undergraduates regarding learning English, The International Journal of Educational Researchers, Vol.6, No.2, 2015.

[12] P. G. Kampylis, S. Bocconi, Y. Punie. Towards a mapping framework of ICT enabled innovation for learning, Spain, Joint Research Center, Institute for Prospective Technological Studies, 2012.

[13] Y. Kirkgöz. A case study of teachers' implementation of curriculum innovation in English language teaching in Turkish primary education, Teaching and Teacher Education, Vol.24, 1859-1875, 2008.

[14] K. Kirkland, D. Sutch. Overcoming the barriers to educational innovation, Bristol, Futurelab, 2009.

[15] M. Langworthy, L. Shear, B. Means. The third lever: Innovative teaching and learning research to support educational change at the system level, OECD, 2010.

[16] J. Merisotis, R. Phipps. What's difference?: Outcomes of distance vs. traditional classroom based learning. Change, Vol.31, No.3, 12-17, 1999.

[17] M. Neo, K. T. Neo. Innovative teaching: Using multimedia in a problem-based learning environment, Educational Technology and Society, Vol.4, No.4, 19-31, 2001.

[18] OECD. Education today: The OECD perspective, Paris, OECD, 2009.

[19] OECD. Inspired by technology, driven by pedagogy: A systemic approach to technology-based school innovations, Paris, OECD, 2010.

[20] F. Pisanu, P. Menapace. Creativity and innovation: Four key issues from a literature review, Creative Education, Vol.5, No.3, 145-154, 2014.
[21] P. Sahlberg. Creativity and innovation for lifelong learning, Lifelong Learning in Europe Journal, Vol.14, 56-60, 2009.

[22] P. Sahlberg, D. Oldroyd. Pedagogy for economic competitiveness and sustainable development, European Journal of Education, Vol.45, No.2, 280-299, 2010.

[23] D. G. Salampasis. Enhancing creativity and innovation including entrepreneurship at all levels of education and training, Brussels, ECET, 2013.

[24] D. Schneckenberg. Understanding the real barriers to technology enhanced innovation in higher education, Educational Research, Vol.51, No.4, 411-424, 2009.

[25] H. Shapiro, J. Haahr, I. Bayer, P. Boekholt. Background paper on education, Danish technological Institute and Technopolis for the European Commission, DG Education and Culture in the context of a planned Green Paper on innovation, 2007.

[26] L. Shavinina. How to develop innovators? Innovation education for the gifted, Gifted Education International, Vol.29, 54-68, 2013.

[27] J: Simplico. Teaching classroom educators how to be more effective and creative teachers, Education, Vol.120, No.4, 675-680, 2000.

[28] O. A. Ungar, Y. E. Alkakay. Teachers in a world of change: Teachers' knowledge and attitudes towards the implementation of innovative technologies in schools, Interdisciplinary Journal of E-Learning and Learning Objects, Vol.7, 291-303, 2011.

[29] J. Voogt. Teacher factors associated with innovative curriculum goals and pedagogical practices: differences between extensive and non-extensive ICT using science teachers, Journal of Computer Assisted Learning, Vol.26, 453-464, 2010.

[30] D. Watson. Understanding the relationship between ICT and education means exploring innovation and change, Educational Information Technologies, Vol.11, 199-216, 2006.

[31] K. W. Seemann. Preparing learners for the innovation economy: It's time to rethink almost everything about technology education, Design and Technology Education: An International Journal, Vol.11, No.2, 31-40, 2006.

[32] F. Avvisati, G. Jacotin, S. Vincent-Lancrin. Educating higher education students for innovative economies: What international data tell us, Tuning Journal for Higher Education, Vol.1, No.1, 223-240, 2013.

[33] Y. Zhao. A world at risk: An imperative for paradigm shift to cultivate $21^{\text {st }}$ century learners, Society, Vol.52, No.2, 129-135, 2015.

[34] M. Turcsányi-Szabó. Aiming at sustainable innovation in teacher education - from theory to practice, Informatics in Education, Vol.11, No.1, 115-130, 2012.

[35] T. Wagner. The global achievement gap: Why Even Our Best Schools Don't Teach the New Survival Skills Our Children Need - and What We Can Do about It, Basic Books, New York, 2010.

[36] P. Sahlberg. Education reform for raising economic competitiveness, Journal of Educational Change, Vol.7, No.4, 259-287, 2006. 
[37] E. M. Rogers. Diffusion of Innovations, $5^{\text {th }}$ Edition, Free Press, New York, 2003.

[38] K. Ala-Mutka, Y. Punie and C. Redecker. ICT for learning, innovation and creativity, European Commission, Joint Research Center, Spain, 2008.

[39] C. M. Christensen, C. W. Johnson, M. B. Horn. Disrupting Class: How Disruptive Innovation Will Change the Way the World Learns, McGraw Hill, New York, 2008.

[40] J. A. Meirink, J. Imants, P. C. Meijer, N. Verloop. Teacher learning and collaboration in innovative teams, Cambridge
Journal of Education, Vol.40, No.2, 2010.

[41] Z. Xu, H. Chen. Research and practice on basic composition and cultivation pattern of college students' innovative ability, International Education Studies, Vol.3, No.2, 51-55, 2010.

[42] P. Sahlberg. Creativity and innovation through lifelong learning, Journal of Lifelong Learning in Europe, Vol.14, No.1, 53-60, 2009.

[43] T. Falch, C. Mang. Innovations in education for better skills and higher employability, European Expert Network on Economics of Education, 2015. 